\title{
Glacial-interglacial variability in ocean oxygen and phosphorus in a global biogeochemical model
}

\author{
V Palastanga ${ }^{1}$, C. P. Slomp ${ }^{1}$, and C. Heinze ${ }^{2}$ \\ ${ }^{1}$ Department of Earth Sciences-Geochemistry, Faculty of Geosciences, Utrecht University, Budapestlaan 4, Utrecht, 3584 CD, \\ The Netherlands \\ ${ }^{2}$ University of Bergen, Geophysical Institute and Bjerknes Centre for Climate Research, Allégaten 70, 5007 Bergen, Norway \\ Correspondence to: V. Palastanga (v.palastanga@uu.nl)
}

Received: 28 March 2012 - Published in Biogeosciences Discuss.: 19 April 2012

Revised: 19 December 2012 - Accepted: 20 December 2012 - Published: 11 February 2013

\begin{abstract}
Increased transfer of particulate matter from continental shelves to the open ocean during glacials may have had a major impact on the biogeochemistry of the ocean. Here, we assess the response of the coupled oceanic cycles of oxygen, carbon, phosphorus, and iron to the input of particulate organic carbon and reactive phosphorus from shelves. We use a biogeochemical ocean model and specifically focus on the Last Glacial Maximum (LGM). When compared to an interglacial reference run, our glacial scenario with shelf input shows major increases in ocean productivity and phosphorus burial, while mean deep-water oxygen concentrations decline. There is a downward expansion of the oxygen minimum zones (OMZs) in the Atlantic and Indian Ocean, while the extension of the OMZ in the Pacific is slightly reduced. Oxygen concentrations below $2000 \mathrm{~m}$ also decline but bottom waters do not become anoxic. The model simulations show when shelf input of particulate organic matter and particulate reactive $\mathrm{P}$ is considered, low oxygen areas in the glacial ocean expand, but concentrations are not low enough to generate wide scale changes in sediment biogeochemistry and sedimentary phosphorus recycling. Increased reactive phosphorus burial in the open ocean during the LGM in the model is related to dust input, notably over the southwest Atlantic and northwest Pacific, whereas input of material from shelves explains higher burial fluxes in continental slope and rise regions. Our model results are in qualitative agreement with available data and reproduce the strong spatial differences in the response of phosphorus burial to glacial-interglacial change. Our model results also
\end{abstract}

highlight the need for additional sediment core records from all ocean basins to allow further insight into changes in phosphorus, carbon and oxygen dynamics in the ocean on glacialinterglacial timescales.

\section{Introduction}

Phosphorus $(\mathrm{P})$ is an essential nutrient in marine biogeochemistry and is believed to limit primary productivity on geological timescales (Tyrrell, 1999). Variations in P availability in the open ocean thus have the potential to impact primary productivity and ocean oxygenation during glacials. In the present-day ocean, a major proportion of $\mathrm{P}$ burial takes place on continental margins ( $>50 \%$, Ruttenberg, 1993; Filippelli, 1997). During glacial periods, P burial on shelves was likely reduced because of sea level fall, whereas the erosive transfer of particulate material containing reactive $P$ and degradable carbon from shelves to the open ocean was likely enhanced (Ruttenberg, 1993). As a consequence, the inventory of $\mathrm{P}$ in the open ocean, primary productivity and $\mathrm{CO}_{2}$ drawdown may have increased, whereas ocean oxygen may have declined. This potential impact on productivity and $\mathrm{CO}_{2}$ was first brought forward by Broecker (1982) in the so-called shelf-nutrient hypothesis.

At present, there are still very few sediment core records for $\mathrm{P}$ available to test this hypothesis. In one of the few studies presenting such data, Filippelli et al. (2007) show that there was an increase in $\mathrm{P}$ burial during glacial times at deep 
ocean sites in the Southern Ocean and the equatorial Pacific. They argue that increased transfer of $\mathrm{P}$ from the margins to the deep sea drove enhanced biological productivity and ultimately led to elevated rates of $\mathrm{P}$ sedimentation. Tamburini and Föllmi (2009), in contrast, report a slight decrease in P burial at deep-sea locations in the North Atlantic and Pacific during glacial times (on average $12 \%$ ). These authors suggest that the $P$ released from shelves during glacials remained in the water column and enhanced the P inventory and primary productivity in the ocean.

Decreased $\mathrm{P}$ burial during glacial periods could be explained by lower oxygen concentrations in bottom waters (Tamburini and Föllmi, 2009). There are indications from proxy data that during glacial periods, deep waters were indeed less oxygenated over large areas in the three ocean basins (François et al., 1997; Mangini et al., 2001; Sirocko et al., 2000; Jaccard et al., 2009). Bradtmiller et al. (2010) hypothesized that enrichment of authigenic uranium concentrations in sediments of the equatorial Pacific were the result of a basin-scale deepening of the oxygen minimum zone (OMZ). Changes in sediment P speciation in the North Atlantic during Heinrich events 4 and 5 in the last glacial period have also been suggested to reflect low oxygen (Tamburini et al., 2002).

Several box model studies of carbon and $\mathrm{P}$ dynamics in the ocean confirm that sea level fall could lead to an increase in the ocean phosphate inventory and a decline in ocean oxygen during glacial times (Wallmann, 2003; Tsandev et al., 2008, 2010). Model scenarios that, besides sea level change, include multiple glacial-interglacial cycles and changes in ocean circulation lead to simulated export production rates for glacial periods that are lower or similar to interglacial values (Tsandev et al., 2008). If, however, shelf erosion and rerouting of particulate material from shelves through canyons is included, primary production in the glacial ocean increases relative to interglacials (Tsandev et al., 2010). Under these conditions, deep-sea oxygen levels can drop significantly, promoting enhanced recycling of $P$ relative to organic carbon from sediments (e.g., Algeo and Ingall, 2007), and a further decline in oxygen, without a major change in $\mathrm{P}$ burial (Tsandev et al., 2010). The box models mentioned above do not allow regional patterns in deep-water oxygen, primary productivity and $\mathrm{P}$ burial to be assessed, however, and do not include the effects of changes in iron $(\mathrm{Fe})$ input from dust on ocean productivity (e.g., Bopp et al., 2003; Maher et al., 2010) and the potential interactions with P cycling.

In this study, we expand a biogeochemical ocean model developed for the carbon (C), $\mathrm{P}$ and silicon cycles (Palastanga et al., 2011) with the iron (Fe) cycle to investigate the regional and global scale trends in export production, ocean oxygen and $\mathrm{P}$ on glacial-interglacial timescales. Our major goal is to test whether transfer of organic $\mathrm{C}$ and reactive $\mathrm{P}$ from continental margins to the open ocean during glacials significantly changed the oceans productivity, deep-water oxygenation and $\mathrm{P}$ burial. The model was developed for long-term integrations (i.e., of the order of 10 to $100 \mathrm{kyrs}$ ), and includes a detailed representation of sediment processes, including anoxic remineralization and redox-dependent $\mathrm{P}$ burial. We present simulations forced by either the glacial or interglacial fields of ocean circulation and atmospheric dust deposition. Our results show that shelf input of particulate organic matter and particulate inorganic $\mathrm{P}$ can significantly impact ocean productivity, deep-water oxygen and, in contrast to what was suggested in previous modeling work, burial of reactive $\mathrm{P}$ in the global ocean. This work also highlights the regional variability in the response of the marine $\mathrm{P}$ cycle to glacial-interglacial change.

\section{Methods}

\subsection{Model description}

We use the model of Palastanga et al. (2011), which is itself a version of the HAMOCC model (Heinze et al., 1999, 2003), expanded to include anaerobic degradation of organic matter in the sediment and a full description of the sedimentary $\mathrm{P}$ cycle. The physical model is based on the annual mean flow of the Hamburg Large Scale Geostrophic ocean circulation model (Maier-Reimer et al., 1993), with a horizontal resolution of $3.5^{\circ} \times 3.5^{\circ}$ and 11 layers in the water column. Given that the resolution of the model is coarse, the dynamics of the continental margins are poorly represented (i.e., there are almost no grid points with depths $<200 \mathrm{~m}$ ). In this section, we briefly describe the modifications made in the model to incorporate a description of the oceanic Fe cycle. A detailed description of the original model formulation can be found in Heinze et al. (2003) and Palastanga et al. (2011).

In the model, it is assumed that all dissolved $\mathrm{Fe}$ is in free inorganic form, and thus bioavailable. Both phosphate $\left(\mathrm{PO}_{4}\right)$ and dissolved $\mathrm{Fe}$ can limit the rate of particulate organic carbon (POC) export production. The annual rate of POC export is determined by the minimum between the uptake rate of $\mathrm{PO}_{4}$ and dissolved $\mathrm{Fe}$ assuming Michaelis-Menten kinetics (Archer and Johnson, 2000). We assume a uniform half saturation constant for $\mathrm{Fe}\left(\mathrm{K}_{\mathrm{fe}}\right)$ equal to $0.003 \mathrm{nM}$ (Archer and Johnson, 2000). The ratio of Fe fixation to organic matter (Fe:C) is $4 \mu \mathrm{mol}: 1 \mathrm{~mol}$ (Parekh et al., 2005). Because of POC mineralization, dissolved $\mathrm{Fe}$ is released back to the water column at this fixed ratio, following the same parameterization used for POC in the original model.

Dissolved $\mathrm{Fe}$ is removed from the water column by scavenging (e.g. precipitation and adsorption) onto sinking particles. Scavenging of dissolved $\mathrm{Fe}$ is modeled as a first order process, with the rate being equal to a rate constant $\left(\mathrm{k}_{\text {scav }}\right)$ times the difference between the actual dissolved $\mathrm{Fe}$ concentration and an apparent solubility constant of $0.6 \mathrm{nM}$ (Johnson et al., 1997; Archer and Johnson, 2000). The latter is aimed to represent the observed relatively constant concentrations of dissolved $\mathrm{Fe}$ in deep waters, possibly a 
consequence of Fe complexation. Scavenging is also limited by the particle load in the water column (Aumont et al., 2003; Parekh et al., 2005). Therefore, similar to Aumont et al. (2003) we assume that the scavenging rate constant $\left(\mathrm{k}_{\text {scav }}\right)$ is given by a minimum uniform rate $\left(0.01 \mathrm{yr}^{-1}\right)$ plus a parti-

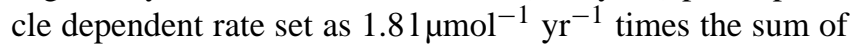
the concentration of the sinking POC, opal, calcite and clay. Assumptions regarding the fate of scavenged $\mathrm{Fe}$ in the water column vary among models. For instance, some models assume that all scavenged $\mathrm{Fe}$ is lost from the system (Aumont et al., 2003), while others consider that a fraction of it goes to the sinking particle pool and remineralizes at depth (Moore and Braucher, 2008, and references therein). Here, a small fraction of scavenged $\mathrm{Fe}$ is added to the flux of particulate $\mathrm{Fe}$ in the water column (as explained below), but this is not subject to dissolution.

The sources of dissolved $\mathrm{Fe}$ in the model are dust and release from sediments. We use the annual mean dust deposition fields from Mahowald et al. (2006), assuming that $\mathrm{Fe}$ accounts for $1.5 \mathrm{wt} \%$ of dust, with a constant solubility in seawater of $1 \%$. Although the aerosol Fe solubility is not a wellconstrained parameter in the ocean (Baker and Croot, 2010), the value used here is in agreement with the observed global average Fe solubility, i.e., $1-2 \%$, and is aimed to simulate realistic concentrations of dissolved $\mathrm{Fe}$ and $\mathrm{PO}_{4}$ at the surface. The release of dissolved Fe from sediments is prescribed using the parameterization of Moore and Braucher (2008), where it is assumed to be a function of the POC flux to the seafloor. However, we adjust the correlation used by Moore and Braucher (2008) to a release of $0.2 \mu \mathrm{mol} \mathrm{Fe} \mathrm{m}{ }^{-2}$ day $^{-1}$ for each $\mathrm{m} \mathrm{mol} \mathrm{C} \mathrm{m}^{-2} \mathrm{day}^{-1}$ settling into the ocean floor, thus reducing the importance of the sedimentary source. By this choice the model simulates reasonable concentrations of surface ocean-dissolved $\mathrm{Fe}$ in open ocean areas which are affected by offshore advection of Fe from margin sediments. The sedimentary flux of dissolved $\mathrm{Fe}$ is finally weighted by the actual ocean bathymetry from the ETOPO2 version 2.0 database to account for the release of Fe from sediments in shelf regions not properly resolved by the model bathymetry (Aumont and Bopp, 2006). Inputs of dissolved $\mathrm{Fe}$ from rivers are considered negligible (Raiswell, 2006).

In contrast to previous models, we include the input of particulate $\mathrm{Fe}$ into the ocean, which we assume consists of $\mathrm{Fe}$ oxides, the cycling of $\mathrm{Fe}$ in sediments and $\mathrm{Fe}-\mathrm{P}$ interactions. It is assumed that $\mathrm{Fe}$ oxides are subject only to vertical (downward) motion in the water column, do not interact with seawater and are eventually deposited into the sediment. Model values for the external input of particulate $\mathrm{Fe}$ are set consistent with mass balance estimates from Raiswell (2006). The total input of particulate Fe from dust is calculated from the atmospheric dust deposition fields of Mahowald et al. (2006). This results in a net atmospheric input of $1.95 \mathrm{Tg} \mathrm{yr}^{-1}$, and in particular, an input of $1.45 \mathrm{Tg} \mathrm{yr}^{-1}$ over the ocean region with depths $>1000 \mathrm{~m}$. The input of particulate Fe from rivers to the ocean area with depths $<1000 \mathrm{~m}$ is assumed to be $2.8 \mathrm{Tg} \mathrm{yr}^{-1}$. Global estimates for the export of Fe oxides from continental margins to the deep ocean are highly uncertain at $4 \pm 12 \mathrm{Tg} \mathrm{yr}^{-1}$ (Raiswell, 2006). As a first approximation, we assume that $1 \mathrm{Tg} \mathrm{yr}^{-1}$ of particulate $\mathrm{Fe}$ from rivers is homogeneously deposited over the ocean surface area with depths between $1000<\mathrm{z}<3500 \mathrm{~m}$. Inputs of Fe oxides from hydrothermal activity and icebergs are neglected in this study, though the latter could be an important source of highly reactive $\mathrm{Fe}$ into the open ocean (Raiswell, 2006). Finally, only $10 \%$ of the total scavenged $\mathrm{Fe}$ is added to the flux of particulate of $\mathrm{Fe}$, while the rest is artificially removed from the system. This fraction is chosen in order to simulate a depositional flux of particulate $\mathrm{Fe}$ in the sediment $\left(52.8 \times 10^{9} \mathrm{~mol} \mathrm{Fe} \mathrm{yr}^{-1}\right)$ which is consistent with pre-

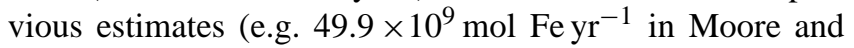
Braucher (2008)).

The sedimentary cycle of $\mathrm{Fe}$ in the model includes mixing and burial of Fe oxides as well as porewater diffusion of dissolved Fe. Precipitation of $\mathrm{Fe}$ to form $\mathrm{Fe}$ oxides is modeled in the aerobic part of the sediment $\left(\mathrm{O}_{2}>5 \mu \mathrm{moll}^{-1}\right)$ following a bimolecular rate law dependent on the porewater $\mathrm{Fe}$ and oxygen concentration (Van Cappellen and Wang, 1996). The rate constant for $\mathrm{Fe}$ oxidation is set to $0.5 \times 10^{7} \mathrm{1}^{-1} \mathrm{~mol} \mathrm{yr}^{-1}$, which lies within the range reported in the literature (Van Cappellen and Wang, 1996; Canavan et al., 2006). Reductive dissolution of $\mathrm{Fe}$ oxides is simulated in the anaerobic part of the sediment $\left(\mathrm{O}_{2}<5 \mu \mathrm{moll}^{-1}\right)$ as a first order reaction proportional to the concentration of $\mathrm{Fe}$ oxides, with no threshold concentration for $\mathrm{Fe}$ oxide reduction. Because dissolution of $\mathrm{Fe}$ oxides affects the benthic release of $\mathrm{PO}_{4}$ in the model due to dissolution of $\mathrm{Fe}$ oxide bound $\mathrm{P}(\mathrm{Fe}-\mathrm{P})$, the dissolution rate was set to a value of $0.025 \mathrm{yr}^{-1}$ to simulate reasonable profiles of Fe oxides in the sediment (Slomp et al., 1996) as well as large-scale distributions of $\mathrm{PO}_{4}$ and $\mathrm{POC}$ export production in the surface ocean. Secondary reactions involving $\mathrm{Fe}$ are not included; in particular, oxidation of organic matter by $\mathrm{Fe}$ oxide reduction is not considered, which is not unreasonable given the relatively low fluxes of organic matter in the model (Wijsman et al., 2002). The rates of Fe-P formation, dissolution and burial in the sediment are deduced from those of Fe oxides assuming a globally uniform $\mathrm{Fe}$ to $\mathrm{P}$ ratio for Fe-P of 20 (Kraal et al., 2010). Overall, the inclusion of the dynamics of $\mathrm{Fe}$ in the model allows a more mechanistic description of the response of the $\mathrm{P}$ cycle to changes in bottom-water oxygenation (e.g., Slomp and Van Cappellen, 2007).

\subsection{Simulations}

Simulations were forced by either the glacial (LGM) or interglacial (preindustrial) fields of annual mean ocean circulation from Winguth et al. (1999) and annual mean dust deposition from Mahowald et al. (2006). For the preindustrial case (reference run), the model was integrated for $200 \mathrm{kyr}$, after which the model is very close to equilibrium (Palastanga et al., 
2011). To simulate scenarios that represent LGM conditions, the model was run from the reference case solution for a period of $120 \mathrm{kyr}$ using LGM forcings. Two scenarios for the LGM were considered: changes in dust input and circulation only (LGM simulation), and increased input of particulate organic matter (POM) and particulate inorganic phosphorus to the open ocean from the continental shelves (LGM simulation + shelf input). Changes in $\mathrm{C}$ and $\mathrm{P}$ retention on shelves linked to the lowering of sea level during glacial times were modeled as a net input of particulate $\mathrm{C}$ and particulate $\mathrm{P}$ into the model surface area with depths $>200 \mathrm{~m}$ and $<2000 \mathrm{~m}$. Given the coarse resolution of the model, detailed modeling of the processes on the shelves is not possible.

Our scenario for shelf input is based on the assumption that during interglacial periods most particulate material is trapped on continental margins (Ruttenberg, 1993), whereas the lowering of sea level during glacial periods caused a shift of sedimentation from shelves to the continental rise and slope regions (i.e the ocean area between 200-2000 m water depth; Wallmann, 2003). Estimates for the flux of POC delivered to the open ocean from erosion of exposed shelves during glacial times were recently summarized by Tsandev et al. (2010). Values range over an order of magnitude, i.e., from 2.3 to $25.0 \mathrm{~T} \mathrm{~mol} \mathrm{Cyr}^{-1}$, which is equivalent to a total input of POC between $1.2 \times 10^{5}-12.5 \times 10^{5} \mathrm{~T} \mathrm{molC}$, assuming a delivery over $50 \mathrm{kyr}$ (Tsandev et al., 2010). In their simulations of erosion from shelves, Tsandev et al. (2010) used

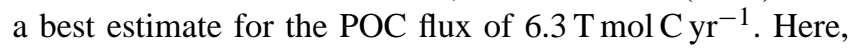
we model the input of POM from shelves as an input of POC equal to $5.0 \mathrm{~T} \mathrm{~mol} \mathrm{Cyr}^{-1}$, which is added at the surface to the model's POC pool. Based on the model's P:C of 122, the latter implies an input of particulate organic $\mathrm{P}$ (POP) from

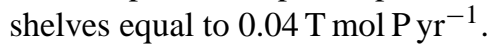

The potential input of particulate $\mathrm{P}$ from shelves to the open ocean during glacials is even less well-quantified than for C. Assuming a decline in shelf area of $50 \%$, Ruttenberg (1993) suggests the total flux of particulate reactive $\mathrm{P}$ could have ranged up to $0.09 \mathrm{~T} \mathrm{~mol} \mathrm{Pyr}^{-1}$ and that a significant proportion of this was likely in the form of authigenic Ca-P. Here, we assume a conservative estimate for the input of particulate inorganic phosphorus (PP) from shelves equal to $0.02 \mathrm{~T} \mathrm{~mol} \mathrm{Pyr}^{-1}$, which is similar to the value used by Tsandev et al. (2010). The flux of PP is added to the model's surface layer and follows the same parameterization for vertical sinking as the other particles in the model (Heinze et al., 2003). We assume that PP is refractory, thus it is not remobilized in the water column and is eventually deposited into the sediment, with authigenic $\mathrm{Ca}-\mathrm{P}$ and $\mathrm{Fe}-\mathrm{P}$ each accounting for $50 \%$ of the total burial.

The global fluxes of $\mathrm{P}$ and $\mathrm{Fe}$ used in the reference run and the LGM simulation, together with the additional inputs of $\mathrm{C}$ and $\mathrm{P}$ assumed in the LGM scenario with shelf input are given in Table 1. Note that because of enhanced dust deposition, the input of dissolved nutrients into the ocean is highest during the LGM. Potential changes in the riverine input of $\mathrm{P}$
Table 1. Global fluxes of nutrients and particulate material in the preindustrial run (reference case) and the LGM simulation.

\begin{tabular}{lcc}
\hline Global fluxes & Preindustrial & LGM \\
\hline Input of dissolved nutrients & & \\
Riverine $\mathrm{PO}_{4}$ & $0.022 \mathrm{~T} \mathrm{~mol} \mathrm{P} \mathrm{yr}^{-1}$ & $0.022 \mathrm{~T} \mathrm{~mol} \mathrm{P} \mathrm{yr}^{-1}$ \\
Atmospheric PO & $0.003 \mathrm{~T} \mathrm{~mol} \mathrm{P} \mathrm{yr}^{-1}$ & $0.007 \mathrm{~T} \mathrm{~mol} \mathrm{P} \mathrm{yr}^{-1}$ \\
Atmospheric Fe & $1.5 \cdot 10^{9} \mathrm{~mol} \mathrm{Fe} \mathrm{yr}^{-1}$ & $3.3 \cdot 10^{9} \mathrm{~mol} \mathrm{Fe} \mathrm{yr}^{-1}$ \\
& & \\
Input of particulate P and Fe & & \\
Authigenic Ca-P (dust) & $0.008 \mathrm{~T} \mathrm{~mol} \mathrm{P} \mathrm{yr}^{-1}$ & $0.022 \mathrm{~T} \mathrm{~mol} \mathrm{P} \mathrm{yr}^{-1}$ \\
Fe oxides bound P (dust) & $0.003 \mathrm{~T} \mathrm{~mol} \mathrm{P} \mathrm{yr}^{-1}$ & $0.004 \mathrm{~T} \mathrm{~mol} \mathrm{P} \mathrm{yr}^{-1}$ \\
Detrital P (dust) & $0.008 \mathrm{~T} \mathrm{~mol} \mathrm{P} \mathrm{yr}^{-1}$ & $0.012 \mathrm{~T} \mathrm{~mol} \mathrm{P} \mathrm{yr}^{-1}$ \\
Fe oxides (dust) & $0.35 \mathrm{~T} \mathrm{~mol} \mathrm{Fe} \mathrm{yr}^{-1}$ & $0.82 \mathrm{~T} \mathrm{~mol} \mathrm{Fe} \mathrm{yr}^{-1}$ \\
Fe oxides (rivers) & $0.68 \mathrm{~T} \mathrm{~mol} \mathrm{Fe} \mathrm{yr}^{-1}$ & $0.68 \mathrm{~T} \mathrm{~mol} \mathrm{Fe} \mathrm{yr}^{-1}$ \\
& & \\
Input of C and P from shelves & - & \\
Particulate organic C (POC) & - & $5.0 \mathrm{~T} \mathrm{~mol} \mathrm{C} \mathrm{yr}^{-1}$ \\
Particulate organic P (POP) & - & $0.04 \mathrm{~T} \mathrm{~mol} \mathrm{P} \mathrm{yr}^{-1}$ \\
Particulate inorganic P (PP) & $-02 \mathrm{~T} \mathrm{~mol} \mathrm{P} \mathrm{yr}^{-1}$ \\
\hline
\end{tabular}

and $\mathrm{Fe}$ associated to decreased weathering and/or changes in the hydrological cycle during glacial periods were not considered (e.g., Föllmi et al., 2009; Tsandev et al., 2008).

\section{Results and discussion}

\subsection{Preindustrial simulation (reference run)}

Because the dynamics of the Fe cycle were not included in previous versions of the model (Palastanga et al., 2011), here we briefly describe the most relevant results of the model reference run. At the surface, dissolved $\mathrm{Fe}$ in the model (Fig. 1a) is high under the dust plumes in the tropical Atlantic and North Indian Ocean, the Arctic Ocean and, locally, in continental margin areas, while concentrations are typically low over the central Pacific Ocean. A quantitative comparison of these model results to observations is difficult due to the sparsity of field data and the coarse resolution of our model. A qualitative comparison of these simulated large-scale features to a compilation of observations from Parekh et al. (2005; Fig. 1b) shows reasonable agreement between the model and data, however. Also, a more recent compilation of $\mathrm{Fe}$ observations from Moore and Braucher (2008) shows that the minimum in Fe concentrations extend well over the central North Pacific (see their Fig. 6a). The largest discrepancies between model and data appear in the eastern equatorial Pacific and at high latitudes in the Southern Ocean, where model values are too high. This is likely the consequence of the lack of scavenging for Fe concentrations below $0.6 \mathrm{nM}$ in the model (Moore and Braucher, 2008). The model distribution of dissolved Fe in deep waters (Fig. 1c) is characterized by a uniform value of $0.6 \mathrm{nM}$ in the open ocean. Higher concentrations are found around 
a)

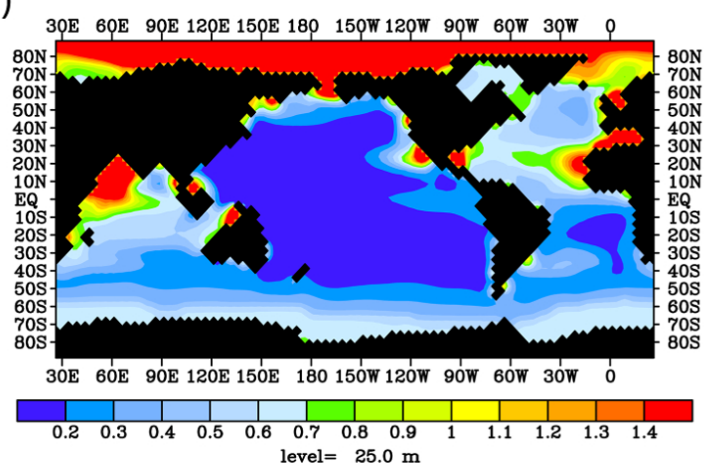

b)

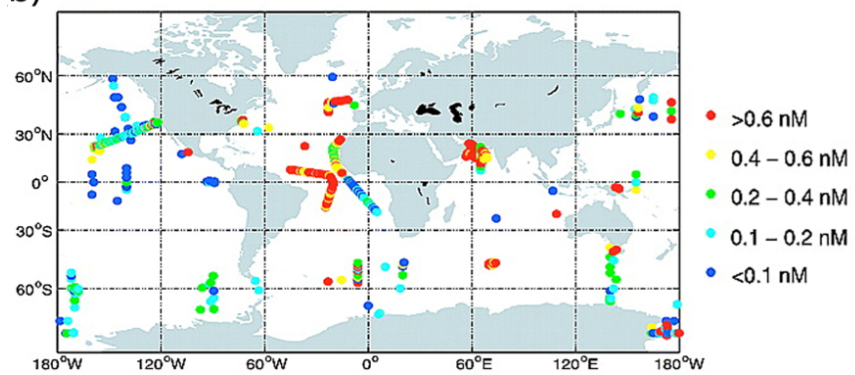

(c)

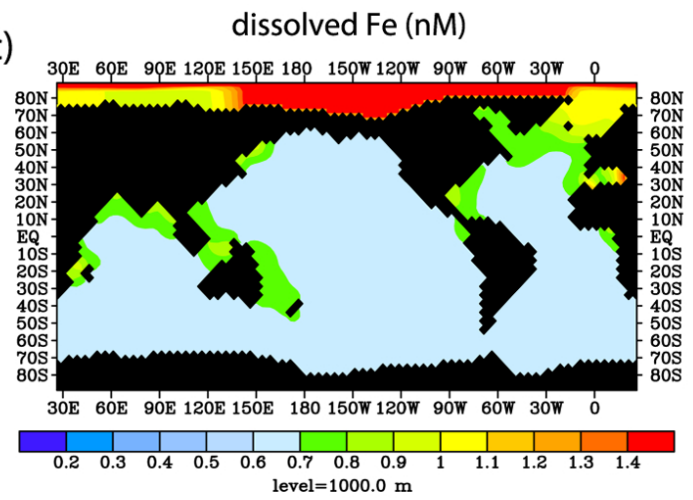

(d)

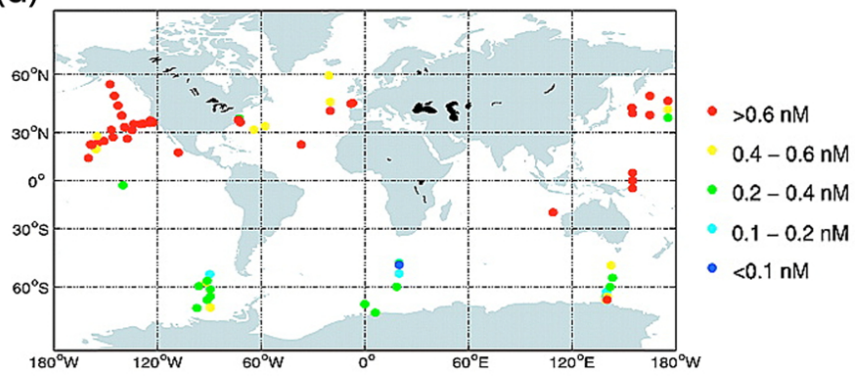

Fig. 1. Dissolved Fe concentrations (in nM) (a) in the surface ocean and (c) 1000-m depth as simulated in the model reference run. Observations of dissolved Fe in (b) surface waters (0 to $25 \mathrm{~m}$ ) and (d) intermediate waters (800 to $1100 \mathrm{~m}$ ) from Parekh et al. (2005).

continental margins where the influence of the sedimentary Fe source is large. The decrease in deep-water Fe concentration relative to the distance from the coast is consistent with observations (Moore and Braucher, 2008; Fig. 1). In general, model Fe concentrations are underestimated in the northeast Pacific and they do not reproduce the observed gradients in the Southern Ocean (Fig. 1d from Parekh et al. (2005)). A more detailed model for $\mathrm{Fe}$ is required to capture the interbasin gradients of the observed deep-water Fe distribution (Parekh et al., 2005).

The annual rate of POC export production predicted by the model $\left(8.96 \mathrm{Pgyr}^{-1}\right)$ is in agreement with estimates from other biogeochemical ocean models (e.g., Aumont et al., 2003). Iron limits productivity over most of the Pacific Ocean (with the exception of the northeastern corner of the basin), the Southern Ocean, and off the western South African margin (not shown). Thus, although the model captures the broad pattern of Fe limitation associated with the well-known high nutrient low chlorophyll (HNLC) oceanic regions, it overestimates their extension into the equatorial Pacific and over the South Pacific subtropical gyre. This is in part related to overly high $\mathrm{PO}_{4}$ concentrations in the equatorial and tropical Pacific in the model due to excessively high upwelling velocities and nutrient trapping, a problem of low-resolution, particle-only models (Heinze et al., 1999; Archer and Johnson, 2000). The excess $\mathrm{PO}_{4}$ in the tropics is then transferred

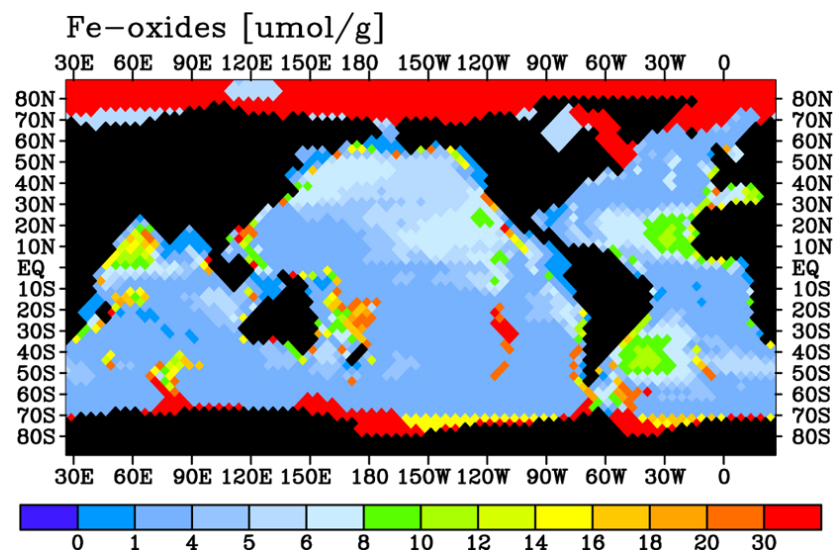

Fig. 2. Fe oxide concentrations averaged over the sedimentbioturbated layer (units in $\mu \mathrm{mol} \mathrm{Fe} \mathrm{g}^{-1}$ ), as simulated in the model reference run.

by lateral advection to subtropical latitudes, causing productivity there to be limited by $\mathrm{Fe}$ availability.

Concentrations of $\mathrm{Fe}$ oxides in the sediment (averaged over the bioturbated layer; Fig. 2) are high in open ocean locations with high rates of atmospheric deposition, such as the tropical and southwest Atlantic and the western Indian Ocean. Vertical profiles of $\mathrm{Fe}$ oxides in the sediment show that reductive dissolution is an important process along 

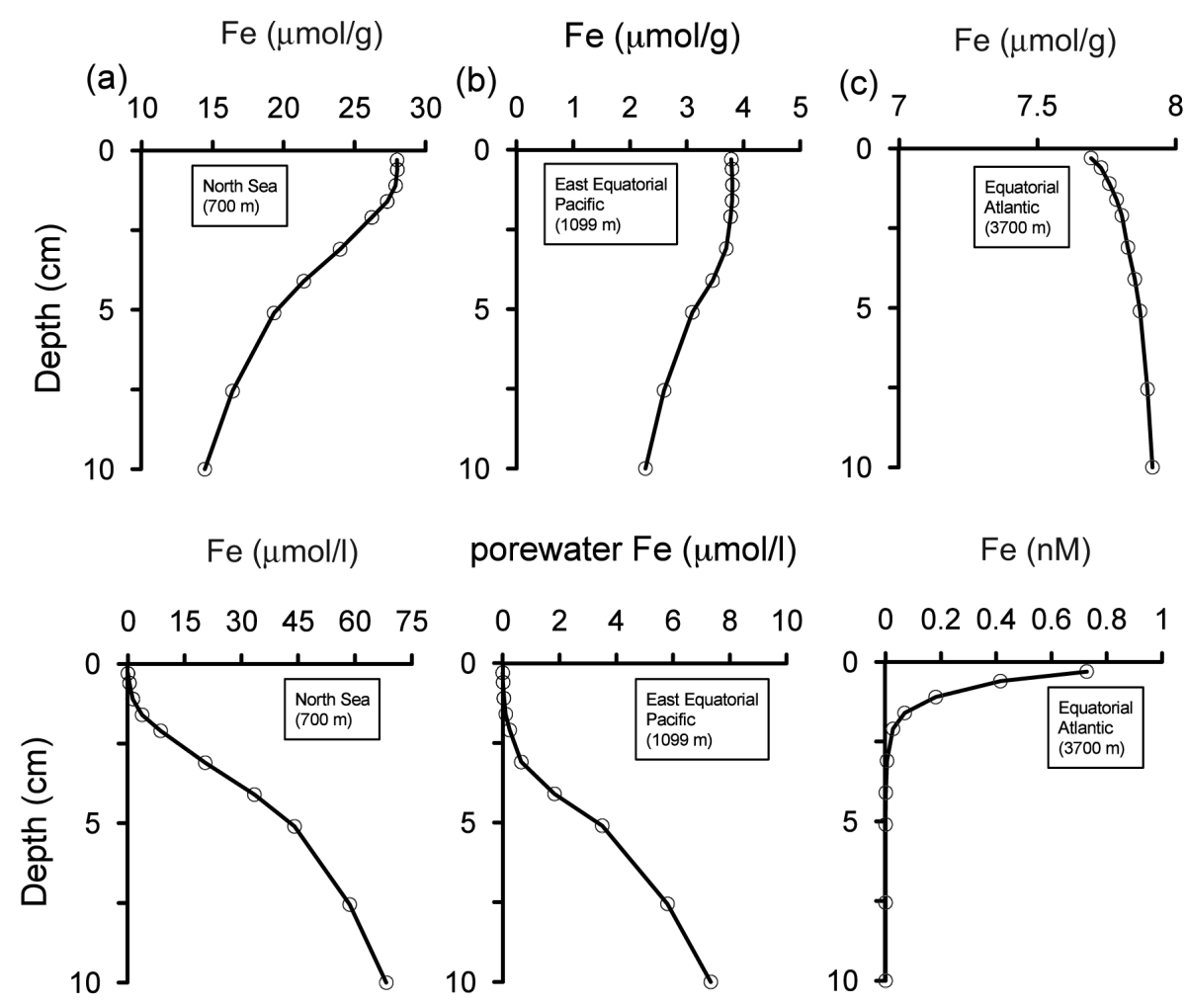

Fig. 3. Vertical profiles of Fe oxides and porewater Fe in the sediment-bioturbated layer at three different locations, as simulated in the model reference run.

continental margins with high rates of POC deposition and anaerobic remineralization (Fig. 3a, b). In contrast, deep-sea settings show net accumulation of $\mathrm{Fe}$ oxides in the sediment, with no recycling of dissolved Fe (Fig. 3c). The sediment $\mathrm{Fe}$ oxide and porewater $\mathrm{Fe}$ concentrations simulated for the North Atlantic continental slope (Fig. 3a) are in good agreement with the range of 20 to $40 \mu \mathrm{mol} \mathrm{g}^{-1} \mathrm{Fe}$ and maximum dissolved Fe of $60 \mu \mathrm{mol} 1$ as measured by Slomp et al. (1996). However, while the model porewater profile indicates constant upward diffusion of Fe, observations show a decrease in Fe concentration at depth in the sediment, which is probably caused by Fe monosulfide and pyrite formation, processes that are not included in the model.

The global distribution of the sedimentary $\mathrm{P}$ phases in the model is similar to that simulated by Palastanga et al. (2011) and is therefore not shown. There are a few small differences in the amplitude of the open ocean maxima in authigenic $\mathrm{Ca}$ $\mathrm{P}$ and Fe-P, mainly because of the use of a different dust field (Mahowald et al., 2006). For further details and a comparison of the model results for reactive $\mathrm{P}$ burial to observations, we refer to Palastanga et al. (2011).

To summarize, expansion of the model of Palastanga et al. (2011) with an oceanic Fe cycle leads to little change in the modeled POC export, oceanic $\mathrm{PO}_{4}$ and oxygen, and $\mathrm{P}$ burial in the preindustrial ocean. However, the response to environ- mental changes such as increased dust inputs of $\mathrm{Fe}$ and $\mathrm{P}$ will differ because only the current model allows both $\mathrm{Fe}$ and $\mathrm{P}$ to be limiting for primary productivity. In addition, inclusion of the dynamics of sedimentary Fe leads to a more mechanistic description of the coupled changes of the sedimentary Fe and $\mathrm{P}$ cycles upon a decline in oceanic oxygen.

\subsection{LGM simulation}

The change in POC export production for the LGM simulation relative to the reference run is presented in Fig. 4a. Relative to interglacial periods, glacial export production decreases over the tropical Pacific, along the eastern Pacific and South African upwelling margins, and in general at high latitudes due to the glacial sea ice cover. Increases are observed over most of the Atlantic and Indian Ocean basins and over the western North Pacific. When compared to indicators of primary production from the paleoclimatic sediment core record during the LGM (Fig.4b from Bopp et al., 2003), the model performs quite well and reproduces most of the observed global trends, with notable exceptions being the eastern equatorial Pacific and the waters off the South African coast. Simulations forced by either the dust or circulation LGM field show that the circulation field is responsible for the spatial distribution and magnitude of the anomalies in productivity at the LGM; nevertheless, the positive trend 
(a)

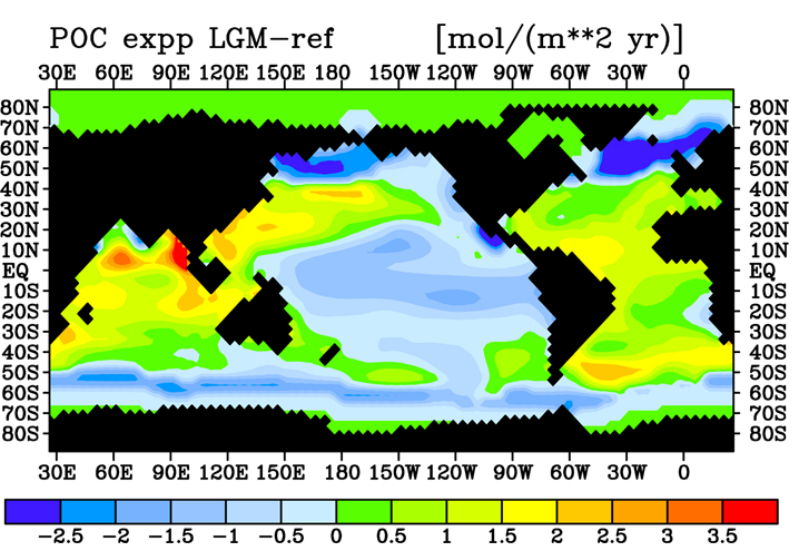

(b)

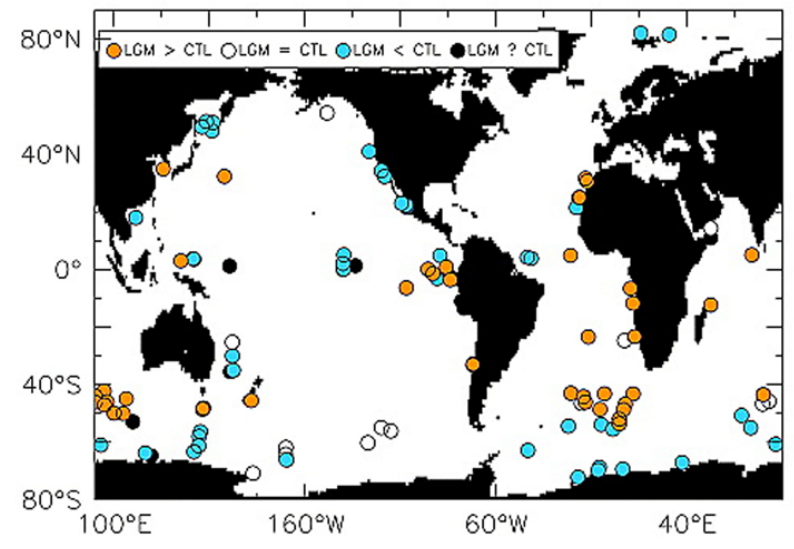

Fig. 4. (a) Change in POC export production in the LGM simulation (without shelf input) relative to the reference run (units in mol m${ }^{-2} \mathrm{yr}^{-1}$ ). (b) Export production (EP) for the LGM minus today, based on paleodata indicators from Bopp et al. (2003); the top panel shows whether the EP increased (LGM $>$ CTL), decreased ( $\mathrm{LGM}<\mathrm{CTL})$, remained the same $(\mathrm{LGM}=\mathrm{CTL})$ or is undetermined (LGM ? CTL) during the LGM compared to today (CTL for control).

induced by dust forcing is locally relevant because, for example, it amplifies the anomalies in the central North Pacific and reverses negative trends in the Arabian Sea and the subtropical South Atlantic.

Global export production of POC shows a moderate increase with time (5\%) in the LGM scenario (Fig. 5a). The same holds for concentrations of $\mathrm{PO}_{4}(+14 \%)$ and oxygen, with the largest simulated changes in oxygen at $1000 \mathrm{~m}$, i.e., the mean deep-water oxygen concentration increases from $112 \mu \mathrm{moll}^{-1}$ in the reference run to $146 \mu \mathrm{mol}^{-1}$ in the LGM case (Fig. 5b, c). Higher glacial oxygen in the model is related to changes in circulation as well as decreasing temperatures, and hence better oxygen solubility in seawater. Oxygen anomalies at 1000-m depth, defined as the LGM concentrations minus those for the preindustrial (Fig. 6a) show large positive trends in the eastern tropical South Pacific and the western North Pacific basin, while weak negative trends are obtained over the tropical Indian and Atlantic oceans. The oxygen distribution at $1000 \mathrm{~m}$ (Fig. 6b) shows three oxygen minima in the tropical basins (north of the Equator in the Pacific), which are above the level of the OMZ (here defined as [O2] $<25 \mu \mathrm{moll}^{-1}$ ). Bottom-water oxygen shows minor changes relative to the preindustrial (not shown).

Changes in sediment-reactive $\mathrm{P}$ in the LGM simulation (Fig. 7) largely follow the global-scale trends in POC export production and are mostly related to changes in authigenic $\mathrm{Ca}-\mathrm{P}$ and organic-P concentrations. Dust forcing alone is responsible for large positive anomalies (of about $10 \mu \mathrm{molg}$ ) in sediment-reactive $\mathrm{P}$ along the North Pacific and South Atlantic subtropical bands, and in general, for a global positive trend in reactive $\mathrm{P}$ concentrations at the LGM. Reactive P burial rates are lower along the eastern Pacific and off South Africa, where there is normally upwelling, and in the northern North Atlantic, the central Pacific and parts of the Southern Oceans (Fig. 8a)

Overall, the global rate of reactive $\mathrm{P}$ burial in the LGM simulation $\left(0.032 \mathrm{~T} \mathrm{molPyr}^{-1}\right)$ is $10 \%$ higher than the preindustrial value. Global POC burial also increases by $9 \%$ relative to the reference case, with the largest positive anomalies along the western Atlantic and Indian Ocean margins (not shown). These results highlight that changes in dust input and oceanic circulation during the LGM contributed to spatial variations in reactive $\mathrm{P}$ burial in the open ocean.

\subsection{LGM simulation with shelf input}

With the LGM simulation with shelf input, we analyze the combined effects of including the input of both POM (i.e., POC+POP) and PP into the model continental slope and rise regions. Relative to the preindustrial simulation, this leads to a factor increase of almost 1.5 in global export production and a factor 2.5 increase in the $\mathrm{PO}_{4}$ inventory (Fig. 5a, b). Because of the large increase in surface $\mathrm{PO}_{4}$, POC export production becomes limited by Fe availability in most ocean basins (with the exception of the high productivity near coastal areas). Global mean oxygen concentrations decrease by $12 \%$, but the largest change in oxygen occurs around $1000-\mathrm{m}$ depth ( $-20 \%$ relative change), where the mean oxygen concentration decreases to $89 \mu \mathrm{M}$ (Fig. 5c). The distribution of oxygen anomalies at $1000 \mathrm{~m}$ (Fig. 6c) shows a predominance of negative trends, with the largest change being observed over the tropical North Atlantic (oxygen anomalies $-100 \mu \mathrm{M})$ and the subtropical and western Indian Ocean (oxygen anomalies $-70 \mu \mathrm{M}$ ). This leads to a pattern of well-defined tropical OMZs in the three ocean basins (Fig 6d). In particular, the simulation shows a vertical, downward expansion of the Atlantic and Indian Ocean OMZs relative to preindustrial times because of increased input and remineralization of POC in the water column; on 
(a)

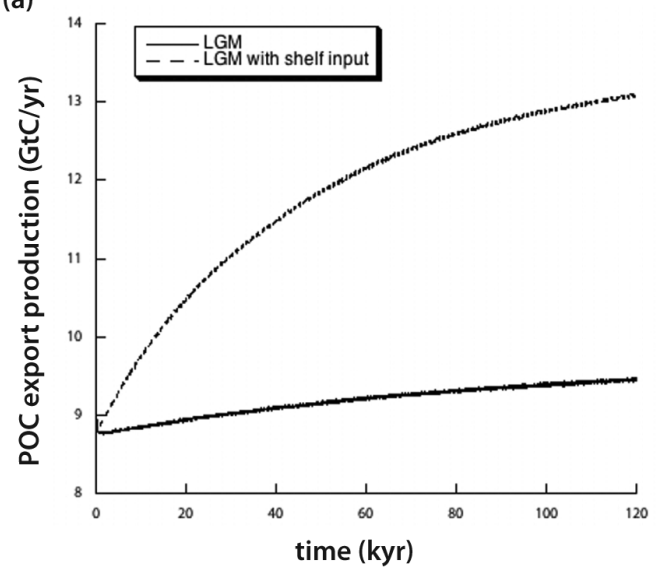

(b)

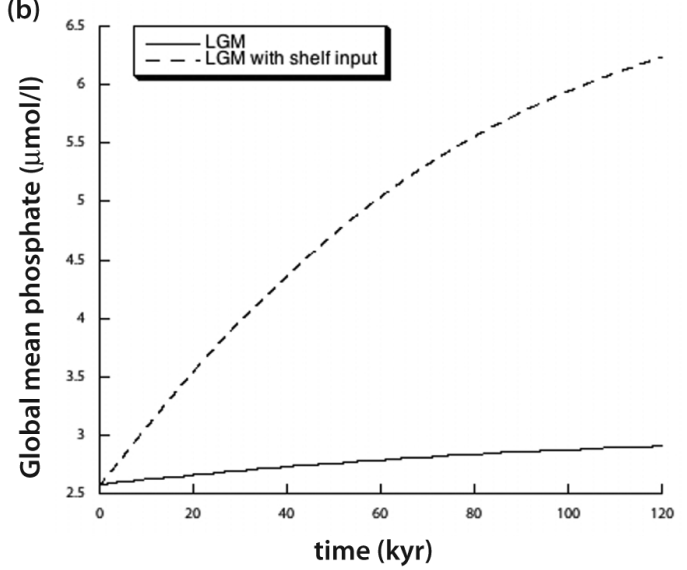

(c)

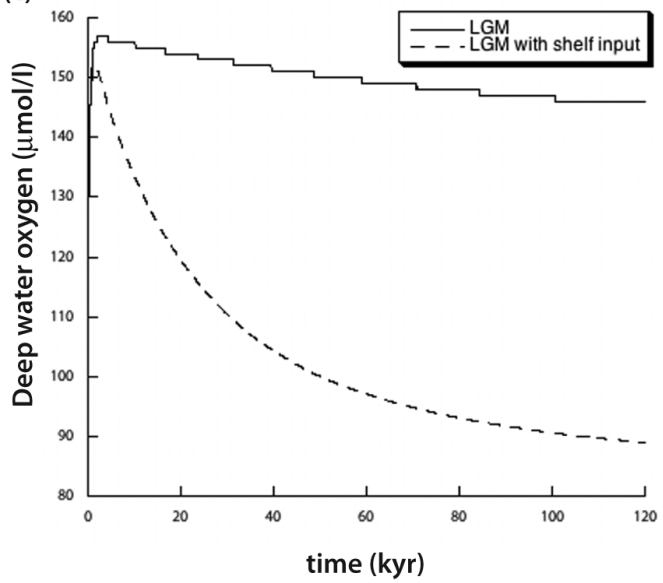

Fig. 5. Transient model response of (a) global POC export production, (b) global mean phosphate concentrations and (c) mean oxygen concentrations at 1000-m depth in the LGM simulation (solid line; LGM) and the LGM simulation with shelf input (dashed line; LGM with shelf input).

the other hand, in the Pacific the extension of the OMZ is slightly reduced and shifted to the north at $1000 \mathrm{~m}$ (Fig. 9). Although bottom waters do not reach suboxic levels, bottom- water oxygen concentrations along high-productivity margins range from $25-100 \mu \mathrm{M}$, which is considerably lower than in the LGM simulation without shelf input.

Sediment-reactive $\mathrm{P}$ concentrations increase considerably relative to preindustrial times (Fig. 10). In open ocean areas, this increase is due to a change in sediment-authigenic $\mathrm{Ca}$ $\mathrm{P}$ concentrations (over $90 \%$ of the total $\mathrm{P}$ change), whereas changes in organic $\mathrm{P}$ explain the trends along margins at tropical/subtropical latitudes of the Indian and Atlantic oceans. There is also a significant increase in Fe-P over the nonreducing margin sediments of the Southern Ocean and the northern North Atlantic.

The resulting rate of reactive $\mathrm{P}$ burial $\left(0.1 \mathrm{~T} \mathrm{~mol} \mathrm{Pyr}^{-1}\right)$ is 3 times larger than that in the preindustrial and LGM scenarios. Relative to preindustrial conditions, reactive $\mathrm{P}$ burial increases everywhere except off the eastern equatorial $\mathrm{Pa}$ cific coast, in the northern North Atlantic, and in parts of the Southern Ocean (Fig. 8). As expected, the effect of including the delivery of particulate material from shelves leads to a significant increase in total sedimentation rates and reactive $\mathrm{P}$ burial over the continental slope and rise regions, which accounts for nearly $50 \%$ of the total change in reactive $P$ burial. Note that if the sedimentary cycle of $\mathrm{P}$ were not included in the model, the availability of $\mathrm{P}$ in surface waters and primary productivity would become unrealistically high.

\subsection{Model-data comparison for the LGM}

Records of sedimentary $\mathrm{P}$ concentrations and $\mathrm{P}$ burial during the last glacial period are sparse (Tamburini and Föllmi, 2009). Here, we present a comparison between the glacial trends in $\mathrm{P}$ burial from observations available in the literature and from the two LGM scenarios (Table 2). Given the large variation in the reported data, we categorize the trends as increase, decrease, no change and trend unclear. In general, the model reproduces the observed trends in open ocean locations well, especially in the Southern Ocean and the eastern tropical Atlantic, where the model also simulates an increase in productivity at glacial times. Reactive $\mathrm{P}$ burial in the LGM scenario with shelf input is higher than in the LGM simulation without such an input, but the trends relative to the preindustrial scenario are usually comparable (with the exception of the central equatorial Pacific and the Java plateau).

Model-data discrepancies could be related to the fact that transient changes in circulation are not considered in the model (compare to Tsandev et al., 2010) and to model deficiencies to simulate glacial productivity, for example, in the equatorial Pacific (Bopp et al., 2003). A comparison between model and data near continental margins is difficult due to the coarse resolution of the model. While the model predicts an increase in $\mathrm{P}$ burial on the upwelling margin off the western coast of Mexico, the work of Ganeshram et al. (2002) suggests a significant decrease in phosphogenesis and total $\mathrm{P}$ burial in the region. However, the decrease in productivity and $\mathrm{P}$ burial simulated along most of the eastern tropical 
(a) dissolved oxygen LGM simulation - reference $30 \mathrm{E}$ 6OE $90 \mathrm{E}$ 120E 15OE 180 150W 120W 90W 6OW $30 \mathrm{~W}$ ?

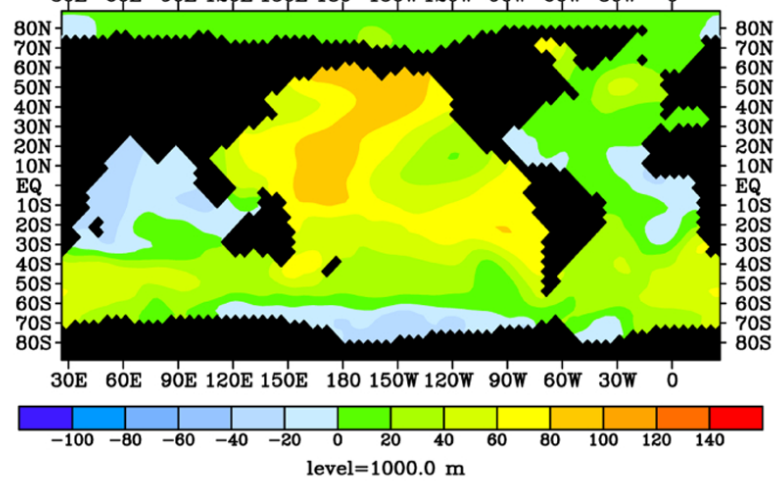

(b)

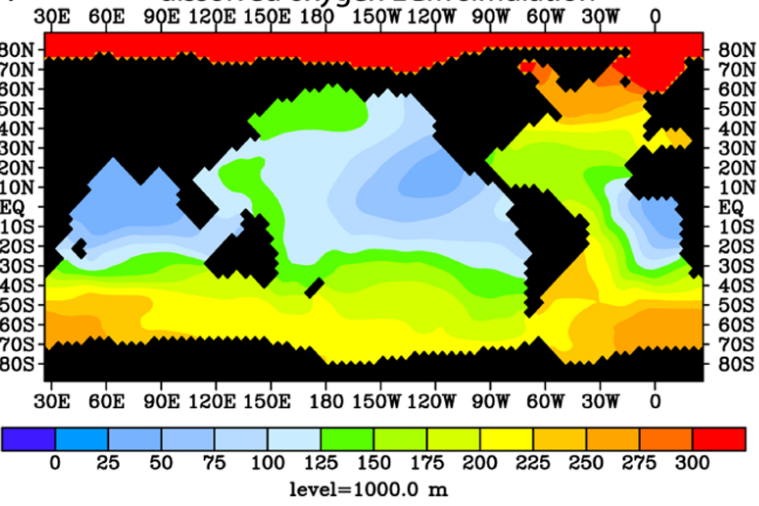

(c)

dissolved oxygen LGM with shelf input - reference

$30 \mathrm{E} \quad 60 \mathrm{E} \quad 90 \mathrm{E} 120 \mathrm{E}$ 150E 180 150W 120W 90W 60W 30W 0

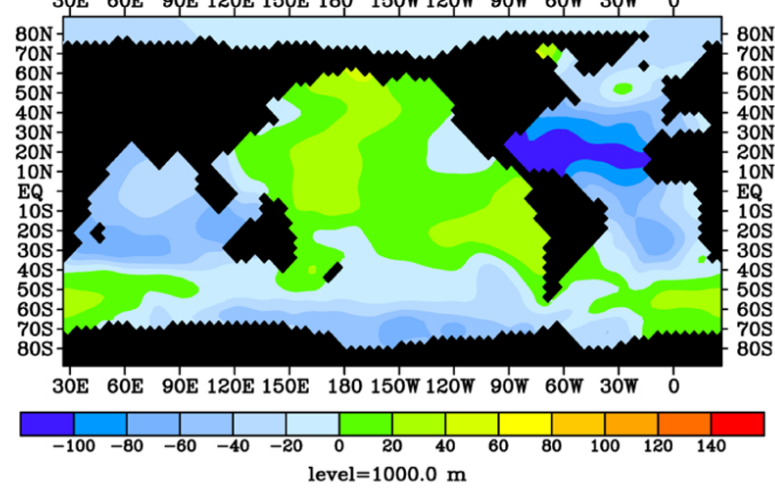

(d)

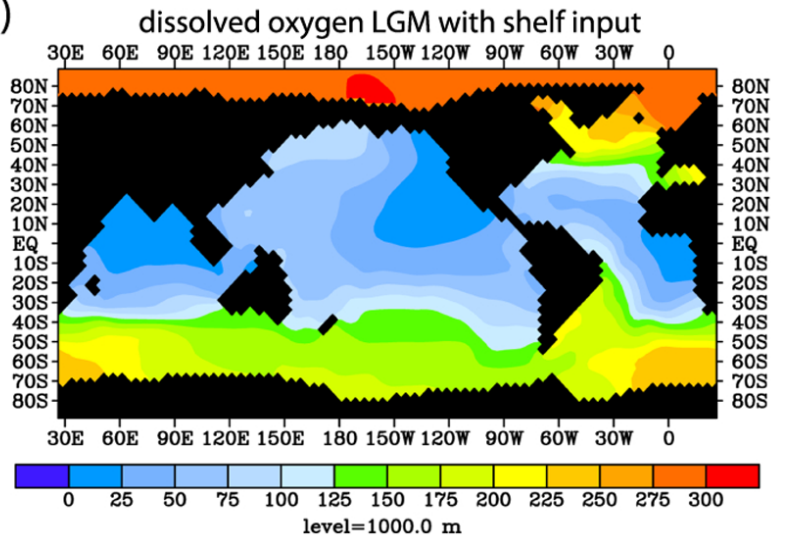

Fig. 6. Oxygen anomalies at $1000 \mathrm{~m}$ relative to the reference run in the model (a) LGM simulation and (c) LGM simulation with shelf input. Oxygen concentrations at $1000 \mathrm{~m}$ in the model (b) LGM simulation and (d) LGM simulation with shelf input. Units in $\mu \mathrm{mol} 1^{-1}$.

Pacific margin is in agreement with a decrease in phosphogenesis in this type of environment.

Low oxygen concentrations, as deduced from proxy records for the glacial ocean, could only be obtained with the model in the LGM scenario with shelf input. Specifically, at 1000-m depth the LGM scenario with shelf input predicts large negative oxygen anomalies over the tropical North Atlantic and the subtropical/western Indian Ocean, and positive oxygen anomalies over most of the Pacific Ocean. At depths below $1000 \mathrm{~m}$, the model simulates negative trends in oxygen over the three ocean basins (only below $2000 \mathrm{~m}$ in the central-eastern tropical Pacific). These modeled trends are in line with proxy data, indicating less oxygenated deep waters in areas of the tropical Atlantic and subarctic Pacific at glacial maxima (Mangini et al., 2001; Jaccard et al., 2009), although the magnitude of the oxygen anomalies in the model are rather weak. For example, oxygen concentrations at e.g. $3000 \mathrm{~m}$ depth do not fall below $125 \mu \mathrm{moll}^{-1}$. On the other hand, the model differs from observations that suggest lower oxygen concentrations in the east equatorial Pacific around $2000 \mathrm{~m}$, and in particular, the model does not support the hypothesis of a downward translation of the $\mathrm{Pa}$ cific OMZ during glacial periods (Bradtmiller et al., 2010). However, the increase in oxygen concentrations in the tropical Pacific at the LGM is largely related to the ocean circulation field. Since the glacial circulation is better constrained by observations in the Atlantic than in the Pacific Ocean (Winguth et al., 1999), future analysis could test the sensitivity of the results in the tropical Pacific against a different glacial circulation field.

Our results are in agreement with previous box-modeling studies that show that the decrease in deep-water oxygenation at glacial times only starts to be significant when large amounts of organic shelf material are delivered to the open ocean (Wallmann, 2003; Tsandev et al., 2010). However, while in those models, redox-dependent $\mathrm{P}$ recycling is suggested to act as a key mechanism to drive glacial trends in ocean productivity and oxygen (Wallmann, 2003) or in $\mathrm{P}$ burial (Tsandev et al., 2010), in the scenarios simulated here bottom-water oxygen concentrations are above levels where preferential P regeneration from sediments is activated. Thus, the response of the model to increased shelf input is rather 
(a) Total reactive P LGM-reference

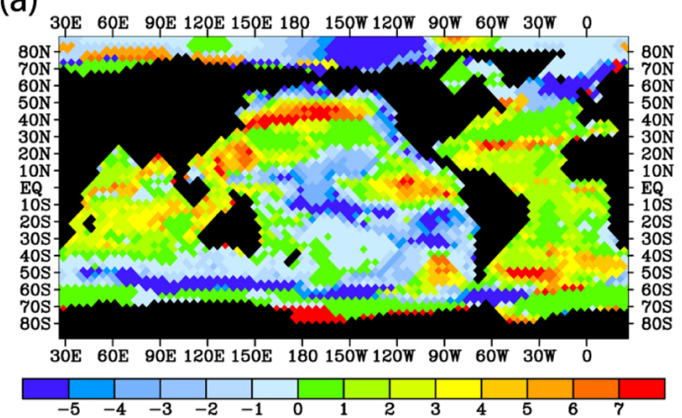

(c)

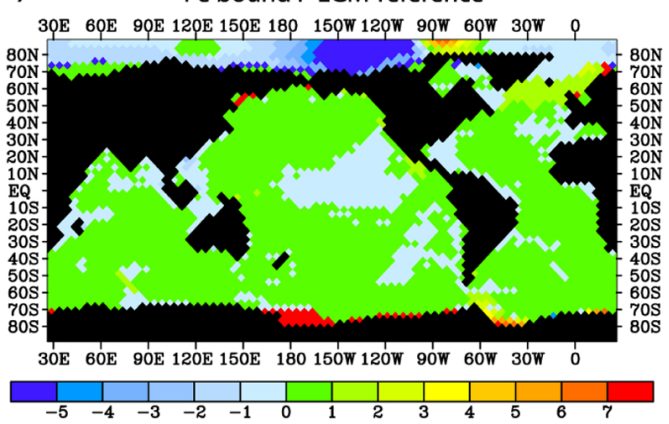

(b)

Authigenic Ca-P LGM-reference

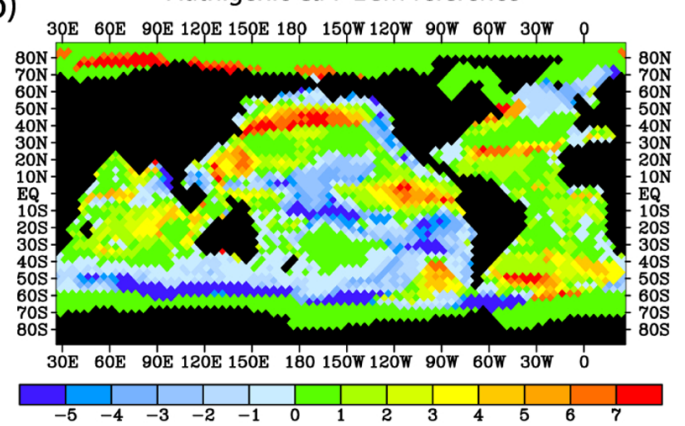

(d)

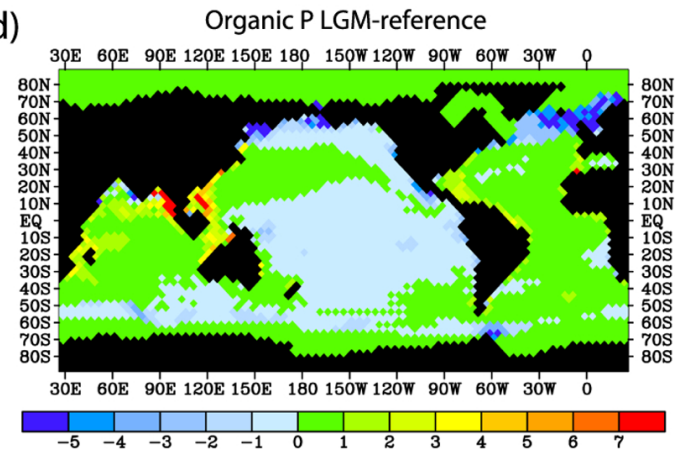

Fig. 7. Sedimentary $\mathrm{P}$ anomalies (averaged over the sediment-bioturbated layer) in the LGM simulation relative to the reference run for (a) total reactive $\mathrm{P}$, (b) authigenic $\mathrm{Ca}-\mathrm{P},(\mathbf{c}) \mathrm{Fe}$ bound $\mathrm{P}$, and (d) particulate organic $\mathrm{P}$. Units in $\mu \mathrm{mol} \mathrm{Pg}^{-1}$.

(a)

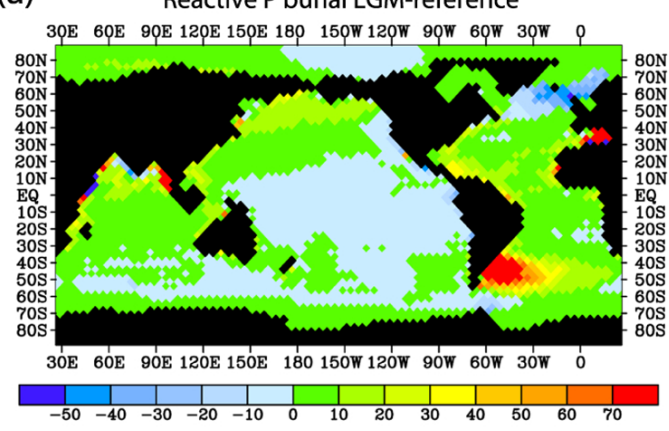

(c) Reactive P burial LGM with shelf input-reference उOE GOE 9OE 120E 15OE 180 150W 120\% 9OW 6OW 30w o

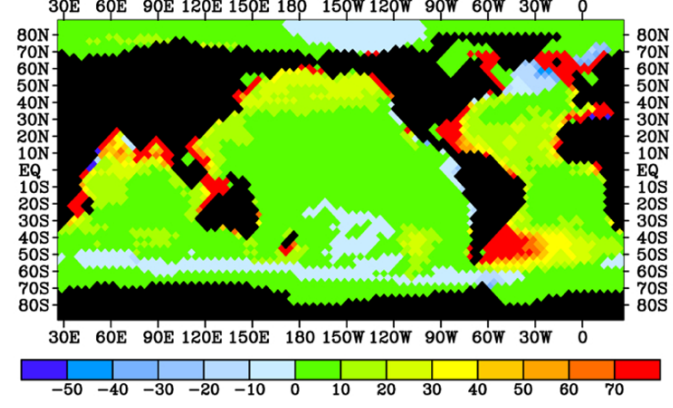

(b) Sedimentation rate LGM-reference $[\mathrm{cm} / \mathrm{kyr}]$

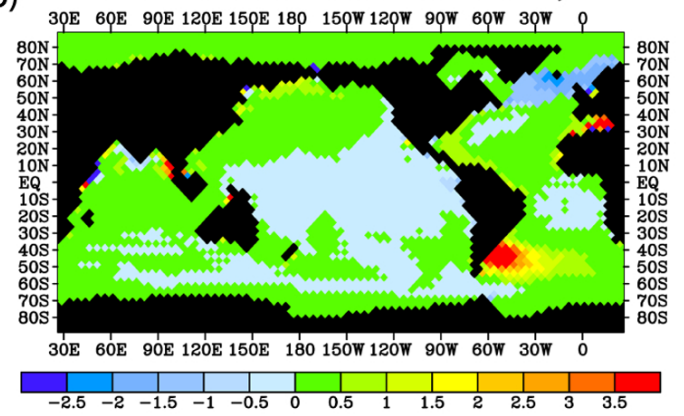

(d) Sedimentation rate LGM with shelf input-reference $[\mathrm{cm} / \mathrm{kyr}]$

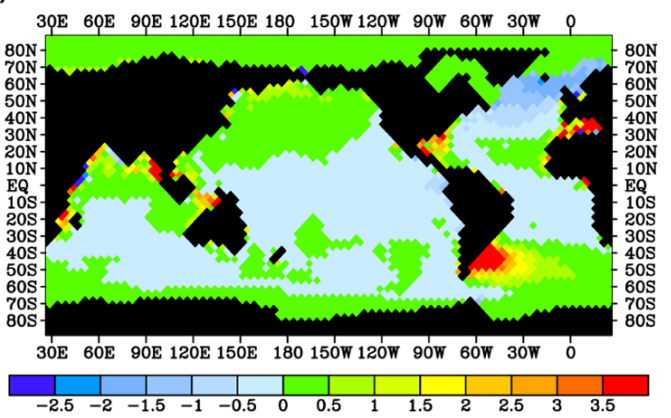

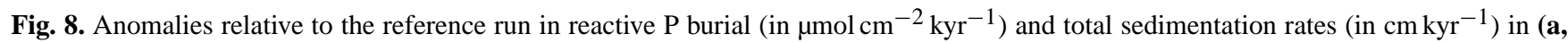
b) the LGM simulation and (c, d) the LGM simulation with shelf input. 
(a) Oxygen section East Indian Ocean
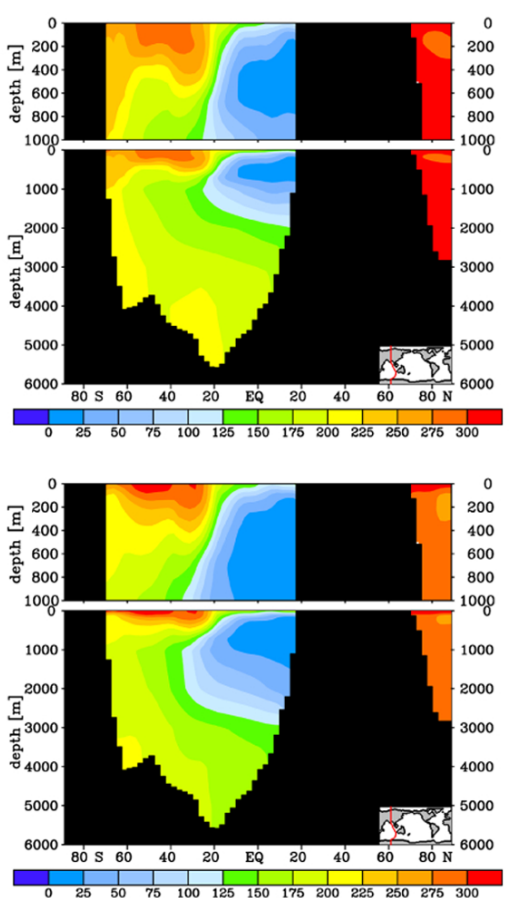

(b) Oxygen section East Pacific
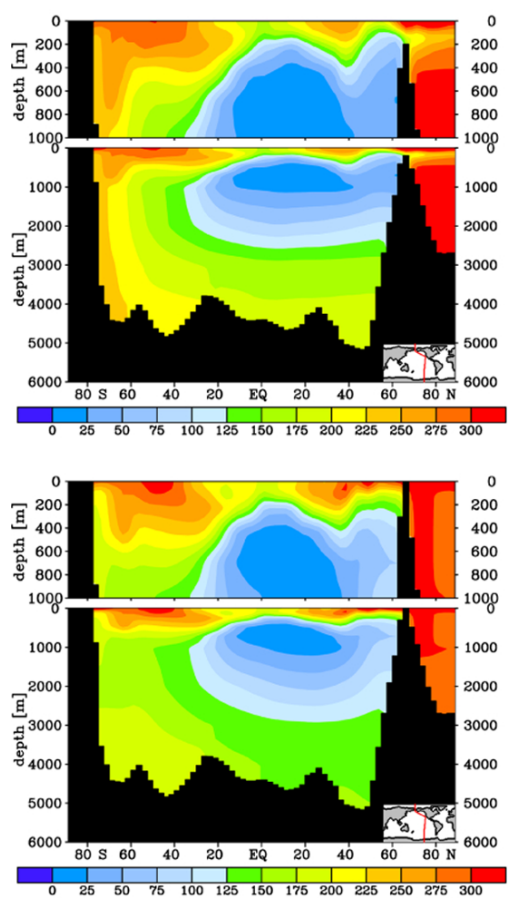

(c) Oxygen section East Atlantic
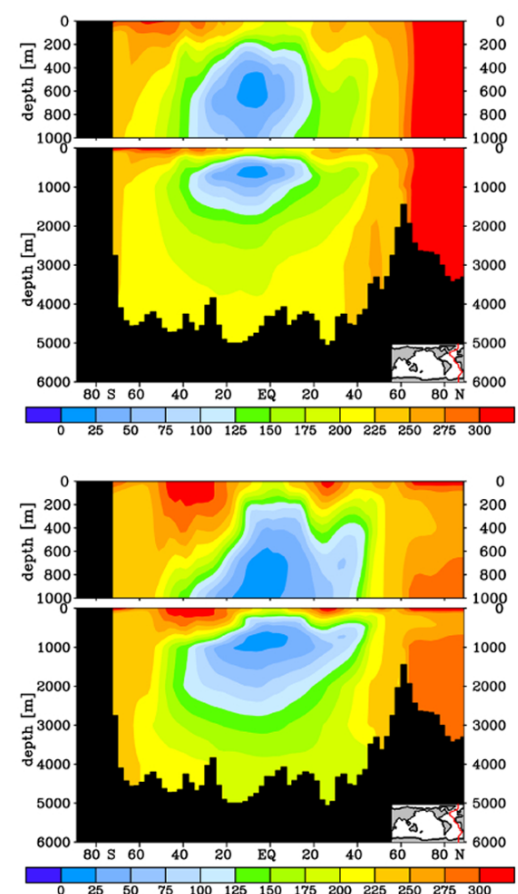

Fig. 9. Oxygen meridional sections in the (a) east Indian Ocean, (b) east Pacific and (c) east Atlantic in the model reference run (top line) and the LGM simulation with shelf input (bottom line). Units in $\mu \mathrm{mol} 1^{-1}$.

(a) Total reactive $\mathrm{P}$ LGM with shelf input-reference 3OE 6OE 9OE 120E 15OE 180 150W 12OW 9OW 6OW 30W

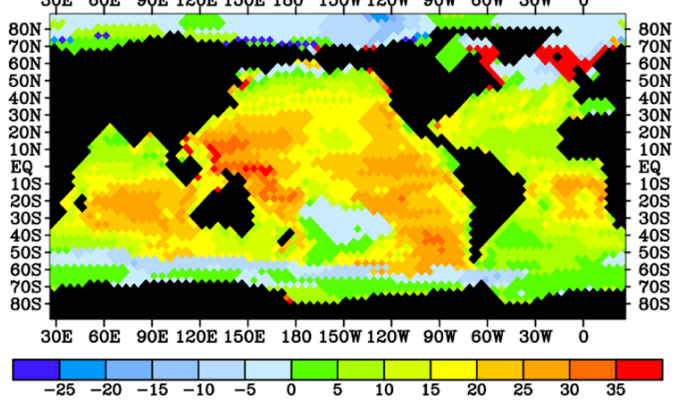

(c)

Fe bound P LGM with shelf input-reference

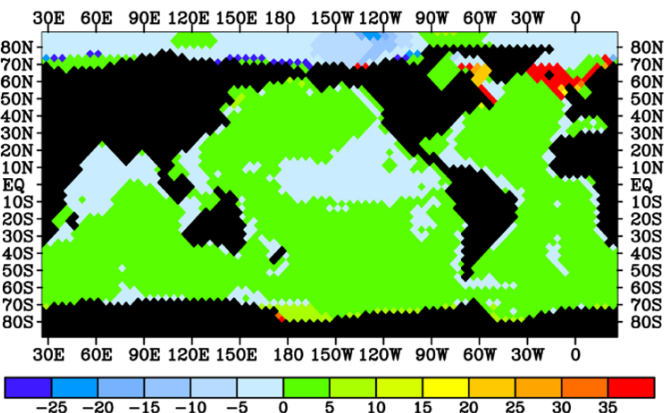

(b) Authigenic Ca-P LGM with shelf input-reference उOE 6OE 9OE 120E 15OE 18O 150W 120W 9OW 6OW 3OW O

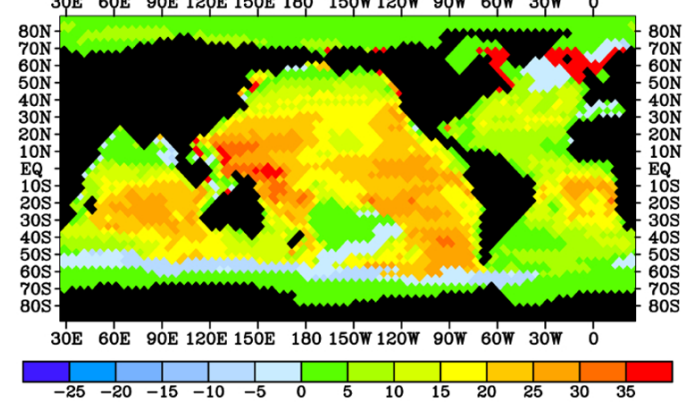

(d) Organic P LGM with shelf input-reference

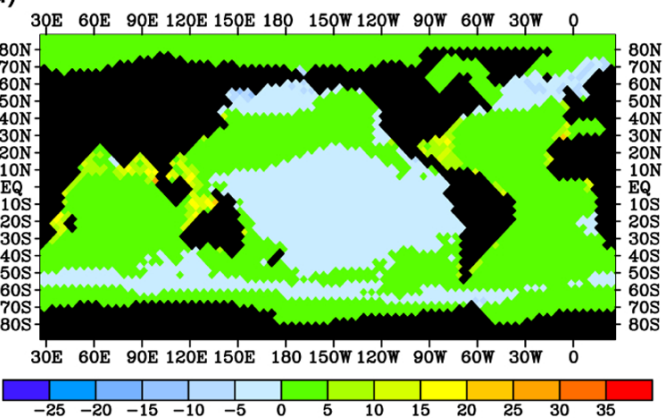

Fig. 10. As for Fig. 7 but for the LGM simulation with shelf input. Note the different color scale relative to Fig. 7. Units in $\mu$ mol $\mathrm{Pg}^{-1}$. 
Table 2. Glacial trends in total $\mathrm{P}$ burial $\left(\delta P_{\text {tot }}\right)$ and reactive $\mathrm{P}$ burial $\left(\delta P_{\text {react }}\right)$ from data and the LGM simulations.

\begin{tabular}{|c|c|c|c|c|c|c|c|c|c|c|}
\hline Latitude & Longitude & Depth & Region & $\begin{array}{l}\text { Data } \\
\delta P_{\text {tot }}\end{array}$ & $\delta P_{\text {react }}$ & Reference & $\begin{array}{l}\text { LGM } \\
\delta P_{\text {tot }}\end{array}$ & $\delta P_{\text {react }}$ & $\begin{array}{l}\text { LGM with shelf input } \\
\qquad \delta P_{\text {tot }}\end{array}$ & $\delta P_{\text {react }}$ \\
\hline \multicolumn{11}{|c|}{ Southern Oceans } \\
\hline-48.00 & 5.00 & 3636 & SAO & + & + & [1] & + & + & + & + \\
\hline-54.00 & -5.00 & 2677 & SAO & + & + & & + & + & + & + \\
\hline-45.00 & 106.00 & 3863 & $\mathrm{SIO}$ & + & + & & + & + & + & + \\
\hline \multicolumn{11}{|c|}{ S. Atlantic/Eq. Pacific } \\
\hline-41.00 & 10.00 & 4620 & SAO & + & + & [2] & + & + & + & + \\
\hline-53.00 & 5.00 & 2807 & SAO & + & + & & + & + & + & + \\
\hline 0.00 & -139.00 & 4298 & EPO & + & + & & - & - & + & + \\
\hline 4.00 & -140.00 & 4432 & EPO & + & + & & - & - & + & + \\
\hline \multicolumn{11}{|c|}{ ODP Sites } \\
\hline 69.00 & -12.00 & 1880 & NAG & $?$ & $=$ & [3] & + & $=$ & + & $=$ \\
\hline 0.00 & -160.00 & 2520 & $\mathrm{JP}$ & - & - & & - & - & + & + \\
\hline 20.75 & -18.06 & 2263 & ETA & $+?$ & + & & + & + & + & + \\
\hline-11.00 & -78.00 & 252 & PEM & $?$ & + & & - & - & - & - \\
\hline-17.75 & 57.60 & 293 & OMM & $+?$ & + & & + & + & + & + \\
\hline 37.00 & 134.00 & 900 & JAPS & $?$ & + & & + & + & + & + \\
\hline \multicolumn{11}{|c|}{ Oman margin } \\
\hline 18.05 & 57.08 & 593 & OMM & N/A & + & [4] & + & + & + & + \\
\hline \multicolumn{11}{|c|}{ Arabian Sea } \\
\hline 23.05 & 66.00 & 1002 & ARS & + & N/A & [5] & + & + & + & + \\
\hline 20.00 & 61.00 & 3570 & ARS & + & N/A & & + & + & + & + \\
\hline \multicolumn{11}{|c|}{ E. Pacific coast } \\
\hline 22.07 & -106.05 & 425 & NWM & - & N/A & [6] & + & + & + & + \\
\hline
\end{tabular}

(1) Trends are categorized as "increase" (+), "decrease" (-), "unclear" (?), "unclear increase" (+?), and "no change" (=). Region abbreviations in the Region column are SAO for South Atlantic Ocean, SIO for South Indian Ocean, EPO for equatorial Pacific Ocean, NAG for North Atlantic Gateways, JP for Java Plateau, ETA for Eastern Tropical Atlantic, PEM for Peru margin, OMM for Oman margin, JAPS for Japan Sea, ARS for Arabian Sea, and NWM for the waters off the northwest Mexican coast. Index numbers for authors in the Reference column are (1) for Latimer and Filippelli (2001), (2) for Filippelli et al. (2007), (3) for Tamburini and Föllmi (2009), (4) for Tamburini et al. (2003), (5) for Schenau et al. (2005), and (6) for Ganeshram et al. (2002).

linear. If we would increase the amount of organic carbon further, the situation would be different: bottom-water anoxia would develop and a positive non-linear feedback from preferential $\mathrm{P}$ regeneration would be initiated. However, there is currently no evidence to support such large inputs. Our work also differs from these previous studies by providing insight in the spatial trends in water column oxygenation and $\mathrm{P}$ burial in simulations of the glacial ocean. Further modeling work should also include the nitrogen $(\mathrm{N})$ cycle, given that nitrogen availability could potentially limit primary productivity in parts of the glacial ocean as well and contribute to spatial trends.

More research is needed to further constrain the delivery fluxes of POM, PP and reactive Fe from shelves to the open ocean during the LGM. This includes a better quantification of the flux of reactive carbon and phosphorus delivered through erosion from the various continental shelves, a quantification of the flux of Fe oxides delivered by icebergs, and insight into the pathways of the iceberg Fe flux into the open ocean and its potential bioavailability (Raiswell et al., 2006).

\section{Conclusions and outlook}

We use a biogeochemical ocean model of the carbon (C), phosphorus $(\mathrm{P})$ and iron $(\mathrm{Fe})$ cycles to compare the trends in ocean productivity, oxygen, and $\mathrm{P}$ cycling at the peak of glacial periods relative to the preindustrial ocean. The model gives a detailed representation of the sedimentary $\mathrm{P}$ dynamics in the open ocean, including anaerobic POC remineralization in sediments and redox dependent $\mathrm{P}$ burial. We specifically assess the role of the input of particulate material from shelves on ocean oxygenation and phosphorus dynamics during glacial times.

To simulate glacial scenarios, we use simulated fields of ocean circulation and atmospheric dust deposition for the LGM. In addition, fluxes of particulate organic matter (POM) and particulate inorganic $\mathrm{P}(\mathrm{PP})$ are added to the model continental rise and slope regions $(200<\mathrm{z}<2000 \mathrm{~m})$ to simulate transfer of particulate matter from shelves to the open ocean during sea level low stands. In the LGM simulation without any inputs of particulate material from shelves, POC export production, global mean phosphate and deep-water oxygen concentrations increase. When shelf input is included, 
the glacial trends in productivity and global mean phosphate concentration are enhanced, whereas the mean deep-water oxygen concentration decreases by $20 \%$ relative to preindustrial times. This supports earlier suggestions from modeling work that erosion of particulate material from shelves plays a key role in the development of low oxygen in the glacial ocean.

Dust is an important source of $\mathrm{P}$ in sediments in open ocean regions (Mahowald et al., 2008). The LGM simulation with shelf input shows that relative to interglacial periods the increase in productivity and reactive $\mathrm{P}$ burial over open ocean regions generally go hand in hand. The largest changes in reactive $\mathrm{P}$ burial are simulated, though, along the continental slope and continental rise and are the result of increased delivery of $\mathrm{P}$ from shelves into those regions. On average, the rate of reactive $P$ burial increases 3 times over the preindustrial value. Despite the limitation of our model to represent the dynamics intrinsic to circulation and coastal sea level changes during glacial-interglacial transitions, the simulations suggest how the spatial distribution of deep-water oxygen and $\mathrm{P}$ burial may have been altered by the transfer of particulate material from shelves to the open ocean.

Additional sediment records of total and reactive P, organic carbon and proxies of water column redox conditions for all open ocean basins are needed for a further reconstruction of marine $\mathrm{P}$ cycling on glacial-interglacial timescales. An area of specific interest is the South Atlantic/Southern Ocean because, based on our model results, an east-west change in P burial (related to enhanced dust deposition during glacial times) is expected here. The model also predicts major changes in reactive $\mathrm{P}$ burial on the eastern and western sides of the North Atlantic basin linked to the glacial input from shelves.

Acknowledgements. This is publication DW-2012-1010 from the Darwin Center for Biogeosciences and A410 from the Bjerknes Centre for Climate Research (BCCR). This is a contribution to core project BIOFEEDBACK of the Centre for Climate Dynamics (SKD) at BCCR. We also acknowledge funding from the Netherlands Organization for Scientific Research (NWO Vidi grant), from Utrecht University (High Potential grant) and the European Union (European Research Council Starting Grant 278364 to C. P. Slomp).

Edited by: A. Paulmier

\section{References}

Algeo, T. J., and Ingall, E.: Sedimentary $\mathrm{C}_{\text {org }}: \mathrm{P}$ ratios, paleocean ventilation, and Phanerozoic atmospheric $\mathrm{pO}_{2}$, Palaeogeography, Palaeoclimatology, Palaeoecology, 256, 130-155, 2007.

Archer, D. E., and Johnson, K.: A model of the iron cycle in the ocean, Global Biogeochem. Cycles, 14, 269-279, 2000.

Aumont, O., and Bopp, L.: Globalizing results from ocean in situ iron fertilization studies, Global Biogeochem. Cycles, 20, GB2017, doi:10.1029/2005GB002591, 2006.

Aumont, O., Maier-Reimer, E., Blain, S., and Monfray, P.: An ecosystem model of the global ocean including $\mathrm{Fe}, \mathrm{Si}$, $\mathrm{P}$ colimitations, Global Biogeochem. Cycles, 17, 525-531, doi:10.1029/2001GB001745, 2003.

Bradtmiller, L.I., Anderson, R. F., Sachs, J. P., and Fleisher, M. Q.: A deeper respired carbon pool in the glacial equatorial Pacific ocean, Earth Pl. Sc. Lett., 229, 417-425, 2010.

Baker, A. R., and Croot, P. L.: Atmospheric and marine controls on aerosol iron solubility in seawater, Mar. Chem., 120, 4-13, 2010.

Bopp, L., K., Kohfel, E., and Le Quéré, C.: Dust impact on marine biota and atmospheric $\mathrm{CO}_{2}$ during glacial periods, Paleoceanography, 18, 1046, doi:10.1029/2002PA000810, 2003.

Broecker, W. S.: Glacial to interglacial changes in ocean chemistry, Prog. Oceanogr., 11, 151-197, 1982.

Canavan, R. W., Slomp, C. P., Jourabchi, P., Van Cappellen, P., Laverman, A. M., and van den Berg, G. A.: Organic matter mineralization in sediment of a coastal freshwater lake and response to salinization, Geochim. Cosmochim. Ac., 70, 28362855, 2006.

Filippelli, G. M.:Controls on phosphorus concentration and accumulation in oceanic sediments, Mar. Geol., 139, 231-240, 1997.

Filippelli, G.M., Latimer, J. C., Murray, R. W., and Flores, J. A.: Productivity records from the Southern Ocean and the equatorial Pacific Ocean: testing the glacial shelf-nutrient hypothesis, Deep Sea Res., 54, 2443-2452, 2007.

Föllmi, K. B, Hosein, R., Arn, K., and Steinman, P.: Weathering and the mobility of phosphorus in the catchments and forefields of the Rhöne and Oberaar glaciers, central Switzerland: Implications for the global phosphorus cycle on glacial-interglacial timescales, Geochim. Cosmochim. Acta, 73, 2252-2282, 2009.

François, R., Altabet, M. A., Yun, E., Sigmans, D. M., Bacon, M. P., Frank, M., Bohrmann, G., Bareille, G., and Labeyrie, L. D.: Contribution of Southern Ocean surface-water stratification to low atmospheric $\mathrm{CO}_{2}$ concentrations during the last glacial period, Nature, 389, 929-935, 1997.

Ganeshram, R. S., Pedersen, T. F., Calvert, S. E., and François, R.: Reduced nitrogen fixation in the glacial ocean inferred from changes in marine nitrogen and phosphorus inventories, Nature, 415, 156-159, 2002. 
Heinze, C., Hupe, A., Maier-Reimer, E., Dittert, N., and Ragueneau, O.: Sensitivity of the marine Si cycle for biogeochemical parameter variations, Global Biogechem. Cycles, 17, 1086, doi:10.1029/2002GB001943, 2003.

Heinze C., Maier-Reimer, E., Winguth, A. M. E., and Archer, D.: A global oceanic sediment model for long-term climate studies, Global Biogeochem. Cycles, 13, 221-250, 1999.

Jaccard, S. L., Galbraith, E. D., Sigman, D. M., Haug, G. H., François, R., Pedersen, T. F., Dulski, P., and Thierstein, H. R.: Subarctic Pacific evidence for a glacial deepening of the oceanic respired carbon pool, Earth Planet Sci. Lett., 277, 156-165, 2009.

Johnson, K. S., Gordon, R. M., and Coale, K. H.: What controls dissolved iron concentrations in the world ocean? Mar. Chem., 57, 137-161, 1997.

Kraal, P., Slomp, C. P., Forster, A., and Kuypers, M. M. M.: Phosphorus cycling from the margin to abyssal depths in the protoAtlantic during oceanic anoxic event 2., Palaeogeogr. Palaeocl., 295, 42-54, 2010.

Latimer, J. C. and Filippelli, G. M.: Terrigenous input and paleoproductivity in the Southern Ocean, Paleoceanography, 16, 627643, 2001

Maher, B. A, Prospero, J. M., Mackie, D., Gaiero, D., Hesse, P. P. and Balkanski, Y.: Global connections between aeolian dust, climate and ocean biogeochemistry at the present day and at the last glacial maximum, Earth Sc. Rev., 99, 61-97, 2010.

Mahowald, N. M., Muhs, D. R., Levis, S., Rasch, P. J., Yoshioka, M., Zender, C. S., and Luo, C.: Change in atmospheric mineral aerosols in response to climate: Last glacial period, preindustrial, modern, and doubled carbon dioxide climates, J. Geophys. Res., 111, D10202, doi:10.1029/2005JD006653, 2006.

Mahowald, N. M., et al.: Global distribution of atmospheric phosphorus sources, concentrations and deposition rates, and anthropogenic impacts, Global Biogeochem. Cycles, 22, GB4026, doi:10.1029/2008GB003240, 2008.

Maier-Reimer, E., Mikolajewicz, U., and Hasselmann, K.: Mean circulation of the Hamburg LSG OGCM and its sensitivity to the thermohaline surface forcing, J. Phys. Ocenogr., 23, 731-757, 1993.

Mangini, A., Jung, M., and Laukenmann, S.: What do we learn from peaks of uranium and of manganese in deep sea sediments?, Mar. Geol., 177, 63-78, 2001.

Moore, J. K. and Braucher, O.: Sedimentary and mineral dust sources of dissolved iron to the world ocean, Biogeosciences, 5, 631-656, doi:10.5194/bg-5-631-2008, 2008.

Palastanga, V., Slomp, C. P., and Heinze,C.: Long-term controls on ocean phosphorus and oxygen in a global biogeochemical model, Global Biogeochem. Cycles, 25, GB3024, doi:10.1029/2010GB003827, 2011.

Parekh, P., Follows, M. J., and Boyle, E. A.: Decoupling of iron and phosphate in the global ocean, Global Biogeochem. Cycles, 19, GB2020, doi:10.1029/2004GB002280, 2005.

Raiswell, R.: Towards a highly reactive iron cycle, J. Geochem. Expl., 88, 436-439, 2006.

Raiswell, R., Tranter M., Benning, L. G., Siegert, M., Death, R., Huybrechts, P., and Payne, T.: Contributions from glacially derived sediment to the global iron (oxyhydr)oxide cycle: Implications for iron delivery to the oceans, Geochim. Cosmochim. Acta, 70, 2765-2780, 2006.
Ruttenberg, K. C.: Reassessment of the oceanic residence time of phosphorus, Chem. Geol., 107, 405-409, 1993.

Schenau, S.J., Reichart, G. J., and de Lange, G. J.: Phosphorus burial as a function of paleoproductivity and redox conditions in Arabian Sea sediments, Geochim. Cosmochim. Ac., 69, 919931, 2005.

Sirocko, F., Garbe-Schonberg, D., and Devey, C.: Processes controlling trace element geochemistry of Arabian Sea sediments during the last 25,000 years, Global Planet. Change, 26, 217-303, 2000.

Slomp, C. P., Epping, E. H. G., Helder, W., and Van Raaphorst, W.: A key role for iron bound phosphorus in authigenic apatite formation in North Atlantic continental platform sediments, J. Mar. Res., 74, 1179-1205, 1996.

Slomp, C. P. and Van Cappellen, P.: The global marine phosphorus cycle: sensitivity to oceanic circulation, Biogeosciences, 4, 155171, doi:10.5194/bg-4-155-2007, 2007.

Tamburini, F. and Föllmi, K. B.: Phosphorus burial in the ocean over glacial-interglacial time scales, Biogeosciences, 6, 501-513, doi:10.5194/bg-6-501-2009, 2009.

Tamburini, F., Föllmi, K. B., Adatte, T., Bernasconi, S. M., and Steinmann, P.: Sedimentary phosphorus record from the Oman margin: new evidence of high productivity during glacial periods, Paleoceanography, doi:10.1029/2000PA000616, 2003.

Tamburini, F., Huon, S., Steinmann, P., Grousset, F. E., Adatte, T., and Föllmi, K. B.: Dysaerobic conditions during Heinrich events 4 and 5: evidence from phosphorus distribution in a North Atlantic deep sea core, Geochim. Cosmochim. Ac., 66, 4069-4083, 2002.

Tsandev, I., Rabouille, C., Slomp, C. P., and Van Cappellen, P. Shelf erosion and submarine river canyons: implications for deep-sea oxygenation and ocean productivity during glaciation, Biogeosciences, 7, 1973-1982, doi:10.5194/bg-7-19732010, 2010.

Tsandev, I., Slomp, C. P., and Van Cappellen, P.: Glacialinterglacial variations in marine phosphorus cycling: Implications for ocean productivity, Global Biogeochem. Cycles, 22, GB4004, doi:10.1029/2007GB003054, 2008.

Tyrrell, T.: The relative influence of nitrogen and phosphorus on oceanic primary productivity, Nature, 400, doi:10.1038/22941, 1999.

Van Cappellen, P. and Wang, R. Y.: Cycling of iron and manganese in surface sediments: a general theory for the coupled transport and reaction of carbon, oxygen, nitrogen, sulfur, iron, and manganese, Am. J. Sci., 296, 197-243, 1996.

Wallmann, K.: Feedbacks between oceanic redox states and marine productivity: A model perspective focused on benthic phosphorus cycling, Global Biogeochem. Cycles, 1084, doi:10.1029/2002GB001968, 2003.

Wijsman, J. W. M., Herman, P. M. J., Middelburg, J. J., and Soetaert, K.: A model for early diagenetic processes in sediments of the continental shelf of the Black Sea, Estuarine, Coastal Shelf Sci., 54, 403-421, 2002.

Winguth, A. M. E., Archer, D., Duplessy, J. C., Maier-Reimer, E., and Mikolajewicz, U.: Sensitivity of paleonutrient tracer distributions and deep-sea circulation to glacial boundary conditions, Paleoceanography, 14, 304-323, 1999. 